\title{
INFESTASI CAPLAK PADA SAPI DI DESA TOLOK KECAMATAN TOMPASO KABUPATEN MINAHASA
}

\author{
Gabriel B. Patodo, M.J. Nangoy*, G.J.V. Assa, A. Lomboan \\ Fakultas Peternakan Universitas Sam Ratulangi Manado.
}

\begin{abstract}
ABSTRAK
Caplak adalah salah satu ektoparasit yang sering ditemui dan dapat menurunkan kualitas dan kuantitas produk peternakan. Kerugian yang ditimbulkan akibat infestasi caplak yaitu kerusakan kulit lokal, anemia, kelumpuhan akibat toksin, dan media transmisi penyakit.

Penelitian infestasi caplak pada ternak sapi di Desa Tolok, Kecamatan Tompaso, Kabupaten Minahasa telah dilaksanakan selama 1 (satu) bulan menggunakan ternak sapi sejumlah 53 ekor untuk menghitung prevalensi, preferensi menurut bagian tubuh, jenis kelamin, dan umur. Pengambilan caplak dilakukan pada bagian kepala, leher, punggung, abdomen, selangkangan, ekor, dan kaki dengan menggunakan pinset pada siang hari. Sampel diawetkan dalam botol berisi alkohol $70 \%$. Penghitungan caplak dilakukan di laboratorium Fakultas Peternakan, Universitas Sam Ratulangi Manado. Hasil penelitian menunjukkan bahwa prevalensi infestasi caplak di Desa Tolok $100 \%$ ( semua sapi yang diamati terinfestasi oleh caplak). Preferensi infestasi caplak pada bagian tubuh ditemukan paling tinggi di selangkangan rata-rata 6,70 ekor caplak/sapi bila dibandingkan dengan bagian tubuh lain yakni; kepala rata-rata $\quad 1,75$ ekor caplak/sapi, kepala rata-rata 1,75 ekor caplak/sapi, leher rata-rata 5,55 ekor caplak/sapi, punggung rata-rata 3,40 ekor caplak/sapi, abdomen rata-rata 4,44 ekor caplak/sapi, kepala rata-rata 1,75 ekor
\end{abstract}

*Korespondensi (Corresponding Authot) Email : mnangoy@unsrat.ac.id caplak/sapi, leher rata-rata 5,55 ekor caplak/sapi, punggung rata-rata 3,40 ekor caplak/sapi, abdomen rata-rata 4,44 ekor caplak/sapi, dan kaki 1,11 ekor caplak/sapi. Preferensi infestasi berdasarkan jenis kelamin ditemukan betina lebih tinggi (rata-rata 32,05 ekor caplak/sapi) bila dibandingkan jantan (20,65 ekor caplak/sapi). Preferensi infestasi caplak berdasarkan umur ternak ditemukan pedet lebih tinggi (27,00 ekor caplak/sapi) bila dibandingkan dengan dewasa (26,15 ekor caplak/sapi).

Kata kunci : Infestasi, Caplak.

\section{ABSTRACT}

INFESTATION OF TICKS ON CATTLE IN TOLOK VILLAGE TOMPASO DISTRICT, MINAHASA. The tick is one of the most commonly encountered ectoparasites on livestock and can degrade its quality and quantity significantly. Risks caused by tick infestation include local skin damage, anemia, paralysis due to toxins, and disease transmission.

A research project on tick infestation was conducted for 1 (one) month in Tolok Village of the Minahasa District due to counted the prevalence of tick infestation on cattle, the preference of tick infestation based on body parts, sex and age.

The research used the survey method, in which tick samples were collected during the day, preserved in a $70 \%$ alcohol solution, and then counted in the laboratory of Faculty of Animal Science, Sam Ratulangi University of Manado. The results showed that tick 
infestation on cattle in Tolok Village yielded $100 \%$ prevalence (all the cattle observed $(n=53)$ were infested by ticks). Infestation preference based on body parts showed the highest on the crotch region (average 6,70 ticks) compared on the head ( average 1,75 ticks), the neck (average 5,55 ticks), the back ( average 3,4 ticks), 4,44 ticks on the abdomen ( average 4,44 ticks), and the legs (1,11 ticks). Infestation preference based on sex showed the highest on female (32,05 ticks) compared on male (20,65 ticks). Finally, based on the cattles' age, the infestation preference were a average of 27 ticks on calfs and 26,15 ticks on adult cattles. Higher infestation preference was found in calfs rather than adult cattle.

Keywords: Infestation, Tick.

\section{PENDAHULUAN}

Caplak adalah salah satu ektoparasit yang sering ditemui dan mampu menurunkan kualitas dan kuantitas produk peternakan. Diperkirakan $80 \%$ ternak di seluruh dunia terserang caplak (Stacey et al., 1978). Kerugian yang ditimbulkan akibat caplak yaitu kerusakan kulit lokal akibat luka, anemia (kurang darah), kurus, dan media transmisi penyakit (Barnett, 1968). Peternak juga mengalami kerugian ekonomi karena terjadi hal-hal seperti penambahan biaya produksi untuk pengobatan, pakan, tenaga kerja, penurunan jumlah sapi akibat kelemahan, penurunan fertilitas pejantan, penurunan berat badan, keguguran, kematian, dan pengafkiran karkas di rumah potong hewan (Seddon, 1952).

Secara umum sistem pemeliharaan ternak sapi terdiri atas intensif, semi intensif dan ekstensif. Sistem ekstensif yang menekankan lahan pengembalaan sebagai sumber pakan, bersifat rawan dan mudah terkena ektoparasit seperti caplak. Caplak memiliki kemampuan hidup yang tahan terhadap perubahan lingkungan dan hidup di rumput. Infestasi caplak dapat ditentukan melalui pengamatan secara langsung di lapangan pada permukaan kulit sapi. Sapi dikatakan terinfestasi dimulai ketika caplak mengisap darah yang dapat menimbulkan kerusakan pada kulit hingga menimbulkan kematian (Wall dan Shearer, 2001). Studi kasus infestasi caplak pada sapi di Kota Banjarbaru ditemukan bahwa 89 ekor (48\%) dari 187 ekor sapi kurus yang dipelihara secara intensif maupun semi intensif terinfestasi caplak (Sulistyaningsih, 2016).

Desa Tolok, Kecamatan Tompaso, Kabupaten Minahasa cukup banyak peternakan rakyat yang memelihara sapi secara ekstensif atau tradisional. Pada umumnya sapi dalam kondisi kurus dan ditemukan luka pada bagian tubuh, sehingga diduga sapi tersebut terinfestasi caplak. 


\section{MATERI DAN METODE PENELITIAN}

Penelitian ini dilaksanakan selama 1 (satu) bulan di Desa Tolok, Kecamatan Tompaso, Kabupaten Minahasa. Tahap penelitian diawali dengan pra penelitian selama 1 (satu) minggu, pada tanggal 8 14 September 2017 dan penelitian selama 3 (tiga) minggu, pada tanggal 21 September - 11 Oktober 2017.

Ternak sapi yang digunakan dalam penelitian ini berjumlah 53 ekor milik dari petani dan peternak Desa Tolok.

Alat dan bahan yang digunakan yaitu: pinset, sarung tangan, jas laboratorium, kaca pembesar, botol sampel, alkohol $70 \%$, cawan petri, kalkulator, alat tulis menulis, dan kamera.

Penelitian ini dilaksanakan dengan menggunakan metode survey. Pengumpulan sampel caplak dilakukan pada siang hari dengan menggunakan pinset yang secara berurutan dimulai dari bagian kepala, leher, punggung, perut atau abdomen, selangkangan dan kaki. Sampel yang terkumpul dimasukkan ke dalam botol yang berisi alkohol $70 \%$ dan berlabel tentang nomor ternak, bagian tubuh ternak, dan tanggal pengambilan sampel. Sampel yang terkumpul dilakukan pengamatan dan penghitungan di laboratorium Fakultas Peternakan, Universitas Sam Ratulangi Manado.
Variabel penelitian ini adalah :

1. Prevalensi infestasi caplak menurut Husna (2014) yaitu:

$$
\left(\frac{\text { jumlah sapi yang terinfestasi }}{\text { jumlah sapi yang diamati }} \times 100 \%\right)
$$

2. Preferensi infestasi caplak menurut bagian tubuh sapi dengan cara menghitung dan membandingkan ratarata caplak di setiap bagian tubuh sapi.

3. Preferensi infestasi caplak menurut jenis kelamin sapi, dengan cara menghitung dan membandingkan ratarata caplak pada sapi jantan dan betina.

4. Preferensi infestasi caplak menurut umur dengan cara menghitung dan membandingkan rata-rata caplak pada sapi pedet dan dewasa.

\section{HASIL DAN PEMBAHASAN}

\section{Prevalensi Infestasi Caplak Pada Sapi}

Menurut Armaidi (2016) prevalensi adalah jumlah keseluruhan kasus yang terjadi pada suatu waktu tertentu di suatu wilayah. Untuk mengetahui prevalensi digunakan rumus sebagai berikut (Husna, 2014):

$$
\text { Prevalensi }=\frac{53}{53} \times 100 \%=100 \%
$$

Keterangan :

jumlah sapi yang terinfestasi yaitu 53 ekor. jumlah sapi yang diamati 53 ekor.

Hasil penelitian prevalensi infestasi caplak pada sapi diperoleh bahwa $100 \%$ 
terinfestasi caplak. Jenis caplak yang ditemukan dapat dilihat pada gambar 1 .

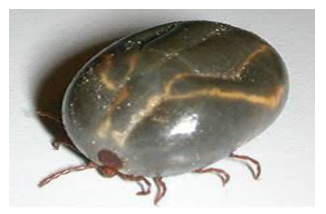

Gambar 1. Caplak pada sapi

Prevalensi infestasi caplak pada sapi di Desa Tolok 100\% karena berdasarkan hasil pengamatan pada umumnya topografi wilayah desa ini berada pada areal padang rumput yang sangat luas dan memiliki kelembaban antara $84 \%$ - $87 \%$. Kelembaban yang tinggi dan area padang rumput sangat cocok bagi perkembangan parasit seperti caplak. Little (1963) menyatakan hampir seluruh sapi yang dilepas di padang pengembalaan di Indonesia terserang berbagai jenis caplak. Begitu juga dengan Subronto (2006) menyatakan daerah tropis yang memiliki kelembaban tinggi dan sinar matahari yang kurang mampu menembus pepohonan, merupakan faktor serasi bagi perkembangan larva termasuk caplak.

Prevalensi infestasi caplak pada sapi di Desa Tolok tertinggi bila dibandingkan dengan beberapa daerah yang lain di Indonesia. Penelitian studi kasus infestasi caplak pada sapi di Kota Banjarbaru oleh Sulistyaningsih (2016) menyatakan jumlah sapi milik 45 orang peternak di 3 kecamatan Kota Banjarbaru yaitu Landasan Ulin, Guntung Payung dan Cempaka sebanyak 89 ekor (48\%) dari
187 ekor sapi terinfestasi caplak. Begitu juga dengan studi kasus infestasi caplak pada sapi lokal Aceh oleh Leliana dan Rizalsyah (2015). Sebanyak 550 caplak dewasa dikumpulkan dari tubuh 500 ekor sapi. Prevalensi infestasi caplak pada sapi lokal Aceh yaitu 47,6\%. Penelitian yang dilakukan oleh Manurung (2002) tentang studi kasus infestasi caplak di Kecamatan Ciracap, Jawa Barat, sapi yang terinfestasi caplak yaitu 44\%, yaitu 82 ekor dari 187 ekor sapi yang dimiliki oleh 45 orang peternak. Begitu juga dari Kecamatan Surade, Jawa Barat, infestasi caplak pada sapi adalah 30\%, yaitu 32 ekor dari 107 ekor sapi yang juga dimiliki oleh 45 orang peternak.

\section{Preferensi Infestasi Caplak Menurut Bagian Tubuh}

Hasil penelitian tentang preferensi atau tingkat kesukaan infestasi caplak menurut bagian tubuh sapi disajikan dalam Tabel 1. Data menunjukkan semua bagian tubuh terinfestasi caplak. Infestasi caplak di bagian tubuh tertinggi terdapat pada selangkangan dengan rata-rata 6.70 ekor caplak/sapi sedangkan bagian tubuh terendah berada pada bagian kaki dengan rata-rata 1,11 ekor caplak/sapi.

Tingginya infestasi caplak di bagian selangkangan, karena bagian ini merupakan tempat yang lembab serta 
Tabel 1. Infestasi caplak pada bagian tubuh sapi.

\begin{tabular}{ccccccc}
\hline Bagian & Kepala & Leher & Pungggung & Abdomen & Selangkangan & Kaki \\
\hline $\begin{array}{c}\text { Rata-Rata (Ekor } \\
\text { caplak/sapi) }\end{array}$ & 1,75 & 5,55 & 3,40 & 4,44 & 6,70 & 1,11 \\
\hline
\end{tabular}

tempat berlindungnya caplak dari inangnya. Menurut Hadi dan Soviana (2000) caplak memiliki organ sensorik yang berfungsi sebagai reseptor kelembaban, kimia dan mekanis. Fungsi kimia berfungsi untuk melacak kimia darah yang menjadi makanan caplak, sehingga caplak menemukan tempat yang tepat untuk berinfestasi. Fungsi mekanis biasanya berperan dalam mencari tempat berlindung yang aman dari gangguan luar. Fielden dan Rechav (1994) juga menyatakan caplak memerlukan bagian kulit yang tipis dan area terlindung pada inang untuk memudahkan proses penghisapan darah. Menurut Willadsen et al. (1984) bahwa caplak tidak menghisap darah begitu saja. Caplak juga mempertimbangkan kepekatan komponen kandungan darah yang dihisapnya, seperti darah merah yang paling banyak membawa oksigen ke jaringan-jaringan tubuh dan plasma protein induk semang.

Pada bagian kaki jarang ditemukan caplak karena bagian ini bebas atau terbuka untuk para predator caplak seperti semut. Barnett (1968) menyatakan predator sejenis semut api (Pheidole megachepala) merupakan predator caplak terkenal. Sekumpulan semut api akan menghalangi larva yang naik ke tubuh sapi dengan cara membunuh larva caplak tersebut dan memakannya. Semut ini juga mengganggu proses pengisapan darah pada caplak di tubuh sapi

\section{Preferensi Infestasi Caplak Keras Menurut Jenis Kelamin}

Hasil rata-rata preferensi atau tingkat kesukaan infestasi menurut jenis kelamin sapi disajikan pada Tabel 2.

Tabel 2. Infestasi caplak berdasarkan jenis kelamin sapi.

\begin{tabular}{lc}
\hline Jenis Kelamin & Rata-Rata (Ekor caplak/sapi) \\
\hline Jantan & 20,65 \\
Betina & 32,05 \\
\hline
\end{tabular}


Sapi betina terinfestasi caplak lebih tinggi bila dibandingkan dengan sapi jantan. Caplak pada sapi betina diperoleh rata-rata 32,05 ekor caplak/sapi, sedangkan sapi jantan 20,65 ekor caplak/sapi. Sapi betina lebih banyak terinfestasi caplak karena dari hasil pengamatan terdapat beberapa sapi betina yang bunting dan baru melahirkan. Menurut Bandini (1999) parasit dengan jumlah yang banyak pada salah satu jenis kelamin kemungkinan dipengaruhi oleh faktor stres. Sapi betina sering mengalami stres bila dibandingkan dengan sapi jantan. Proses bunting, melahirkan dan laktasi umumnya menyebabkan stres pada sapi betina. Adanya faktor stres ini menimbulkan perubahan hormonal pada sapi tersebut dan ketidak seimbangan imunitas sapi.

\section{Preferensi Infestasi Caplak Keras Menurut Umur}

Hasil rata-rata preferensi atau tingkat kesukaan infestasi caplak menurut umur sapi disajikan pada Tabel 3. Dalam tabel tersebut pedet terinfestasi caplak lebih tinggi dari pada dewasa. Pedet dengan umur dibawah 18 bulan diperoleh rata-rata 27,00 ekor caplak/sapi, sedangkan dewasa umur diatas 18 bulan diperoleh rata-rata 26,15 ekor caplak/sapi. Hasil penelitian ini sejalan dengan pendapat Benavides dan Sacco (2007) yang menyatakan bahwa

secara umum pedet lebih sering terkena serangan parasit dibandingkan sapi dewasa. Treverrow (1977) menyatakan pula bahwa larva caplak biasanya berkumpul pada ujung tumbuhan agar mudah berpindah apabila bersentuhan dengan sapi. Selanjutnya larva melekatkan diri dan mengisap darah. Pedet bertubuh pendek, berkeliaran secara aktif di padang gembalaan berpotensi bersentuhan dengan ujung-ujung rumput yang ber larva caplak. Kondisi ini menyebabkan pedet mudah terserang caplak.

Tabel 3. Infestasi caplak berdasarkan umur sapi.

\begin{tabular}{lc}
\hline \multicolumn{1}{c}{ Sapi Pedet dan Dewasa } & Rata-Rata (Ekor Caplak/sapi) \\
\hline Pedet $(18$ Bulan $<)$ & 27,00 \\
Dewasa $(18$ Bulan $>)$ & 26,15 \\
\hline
\end{tabular}




\section{KESIMPULAN}

Berdasarkan hasil dan pembahasan disimpulkan bahwa :

1. Prevalensi infestasi caplak pada sapi di Desa Tolok memperoleh hasil $100 \%$.

2. Preferensi infestasi caplak pada bagian tubuh tertinggi adalah pada bagian selangkangan.

3. Preferensi infestasi caplak sapi betina lebih tinggi dari pada jantan.

4. Preferensi infestasi caplak sapi pedet lebih tinggi dari pada sapi dewasa.

\section{DAFTAR PUSTAKA}

Armaidi, D. 2016. Epidemiologi penyakit menular dan penyakit tidak menular. JMJ 4(2): 195-202

Bandini, Y. 1999. Sapi Bali. Jakarta (ID): Penebar Swadaya.

Benavides, M.V dan M.S. Sacco. 2007. Differential Bos taurus cattle response to Babesia bovis infection. Vet Parasitol 150(1-2): 54-64.

Barnett, G.F. 1968. Boophilus microplus (Acarina : Ixodidae): experimental infestation in cattle restrained from grooming. Exp. Paracitol 26(3): 323-328.

Fielden, L.J. dan Y, Rechav. 1994. Attachment sites of the tick Amblyomma marmoreum on its tortoise host Geochelone pardalis. Experimental and appl. Acarology 18(6): 339-349.
Hadi, U.K. dan S, Soviana. 2000. Ektoparasit: Pengenalan, Diagnose, Dan Pengendalian. IPB Press. Bogor

Husna, S. 2014. Efektivitas Insektisida Terhadap Larva Caplak Sapi (Boophilus microplus) Peternak Sapi Potong Di Jonggol Kabupaten Bogor. Skripsi. Fakultas Kedokteran Hewan, Institut Pertanian Bogor, Bogor Oktober 2014.

Leliana, T. dan Rizalsyah. 2015. Infestasi caplak Ixodidae pada sapi lokal Aceh di Balai Pembibitan Ternak Unggul Dan Hijauan Pakan Ternak (Bptu-Hpt) Indrapuri Kabupaten Aceh besar. Jurnal JESBIO Vol IV(2): 10-13

Little, D. A. 1963. The effect of cattle tick infestation on the growth rate of cattle. Australian Veterinary, Journal, Vol 39(1): 6-10

Manurung, J. 2002. Studi prevalensi infeksi caplak pada sapi di Kecamatan Ciracap dan Kecamatan Surade Kabupaten Sukabumi Jawa Barat serta caracara peternak menanggulanginya. Prosiding. Seminar Nasional Teknologi Peternakan dan Veteriner. Hal 65-73.

Seddon, H.R. 1952. Diseases of Domestic Animals In Australia. Part 3, Protozoan and viral diseases, Catalogue, Canberra

Stacey, B.R, R.E. Williams, R.G. Buckner and J.A. Hair. 1978. Changes in weight and blood composition of hereford and brahman steers in drylot and infeted with adult gulf coast ticks. 
Journal Econ Entomol 71(6): 967970.

Subronto. 2006. Penyakit Infeksi Parasit Dan Mikroba Pada Anjing Dan Kucing. Yogyakarta, Gadjah Mada University Press.

Sulistyaningsih, S. 2016. Studi kasus infestasi caplak Boophilus Microplus pada sapi potong di Kota Banjarbaru. Prosiding. Seminar Nasional Inovasi Teknologi Pertanian. Hal 13201327.

Timmreck, T. 2001. Epidemiologi penyakit menular dan penyakit tidak menular. JMJ 4(2): 195-202,.
Treverrow, N.L. 1977. Aggregation pheromone in two Australian hard ticks, Ixodes holocyclus and Aponomma concolor. Cellular and Molecular Life Sciences, Vol 33(5): 680-682

Wall, R. and D. Shearer. 2001. Veterinary Ectoparasites: Biology, Pathology, \& Control Second Edition. London.

Willadsen, P., D.H. Kemp and R.V. Mckenna. 1984. Blood Meal Ingestion And Utilization As Component Of Host Specificity In The Cattle Tick, Boophilus microplus. Z. Parazitenkunde 70: 415-420. 